\title{
Dependency and Development in a Globalized World: Looking Back and Forward
}

\author{
Patrick Heller • Dietrich Rueschemeyer • \\ Richard Snyder
}

Published online: 8 September 2009

(C) Springer Science + Business Media, LLC 2009

\begin{abstract}
The principles of analysis proposed 40 years ago by Cardoso and Faletto in Dependency and Development in Latin America provide a fruitful way to understand divergent patterns of development in the contemporary era of globalization. This set of analytic principles combines a focus on distinct modes of national insertion into the global economy with a focus on the balance of domestic class forces, the capacity of state institutions, and contingent choices by political actors to explain the contrasting developmental fortunes of countries. The contributors to this special issue demonstrate the vitality of these principles by harnessing them to the dual task of explaining how countries respond to the challenges of globalization and the consequences of these responses. The critical, macroscopic, and possibilistic approach to political economy taken by the contributors offers an exciting and powerful way to understand the problems of development in our globalized world.
\end{abstract}

Keywords Dependency·Development·Globalization · Political economy

\footnotetext{
P. Heller $(\square)$

Department of Sociology, Brown University, Providence, RI, USA

e-mail: Patrick_Heller@brown.edu

D. Rueschemeyer

The Watson Institute for International Studies, Brown University, Providence, RI, USA

e-mail: Dietrich_Rueschemeyer@brown.edu

R. Snyder

Department of Political Science, Brown University, Providence, RI, USA

e-mail: Richard_Snyder@brown.edu
} 
After concluding two terms of serving as President of Brazil in 2003, Fernando Henrique Cardoso visited Brown University many times in the course of 5 years as a Professor-at-Large. At first, his political work stood in the foreground of the lectures and conversations in which he engaged with students and colleagues. He also was generous in reviewing his early intellectual formation and his entry into social science for a younger generation. Yet many of us were eager to turn our discussions back to the classic work, Dependency and Development in Latin America, which he had written with Enzo Faletto four decades ago (Cardoso and Faletto 1979). ${ }^{1}$ A large number of colleagues responded with similarly strong interest when we invited them to a conference at Brown's Watson Institute for International Studies to explore the viability of the core ideas of Dependency and Development in a world that had dramatically changed in the intervening 40 years.

Building on earlier theories of imperialism, both dependency theory and world system theory were scholarly movements insisting on critical perspectives and focusing on power inequalities among nations. Dependency and Development defined in 1967 a turning point in dependency theory, which had come close to a deterministically negative view of development under conditions of international dependence. By contrast, Cardoso and Faletto spoke of dependent development as a realistic, if difficult and complexly conditioned pathway out of the periphery.

This proved immensely important. It freed research that pursued questions inspired by critical perspectives from doctrinaire closure. And it provided a fruitful theoretical frame for such research, anticipating analytic strategies that became very influential much later. Both - the unblinkered critical realism of Cardoso and Faletto and their main analytic strategies - informed rich research streams on a broad variety of issues.

Their "historical structuralism" joined political economy perspectives with an emphasis on class interests, economic organization, and state-society relations. This integrated, comprehensive social science (Rueschemeyer 2009) harkened back to classical theory, but also anticipated what later came to be called the "new institutionalism," which shaped important macro-analyses of revolutions, the welfare state, and democratization as well as developmental success and stagnation. While Cardoso and Faletto did not advance sweeping predictions of what is possible or not, they did not shy away from causal analysis, hypothetically identifying mechanisms such as enclave growth to account for developmental blockages. Such causal analyses could then be tested and elaborated in different country contexts by what we now call historical process tracing.

Two forms of such tracing-focusing on the balance of class forces and state capacity - anticipated and in many cases directly informed a wide range of subsequent comparative work. Scholarly analyses as diverse as Bardhan's (1983) seminal study of India's political economy, Rueschemeyer, Stephens, and Stephens' (1992) and Luebbert's (1991) work on democratization, Brenner's (1985) linking of patterns of industrialization to agrarian relations, Collier and Collier's (1991) study of political trajectories in Latin America, and Huber and Stephens' (2001) and

\footnotetext{
${ }^{1}$ The draft of Dependency and Development in Latin America was completed in 1967 and published in Spanish in 1969 as Dependencia y desarrollo en América Latina. In this article we refer to the English version, which was published in 1979.
} 
Haggard and Kaufman's (2008) comparative studies of welfare states all drew on the basic insight that the balance of class forces is critical to understanding long-term developmental trajectories. Evans' (1979, 1995) and Chibber's (2003) work on the developmental state, much of the literature on East Asian states, and more recent work that has highlighted successful instances of redistributive development in the Global South (Heller 1999; Snyder 2001; Sandbrook et al. 2007) all owe a direct debt to Cardoso and Faletto's claim that under certain circumstances states could become proactive agents of accelerated development, even in contexts of overall dependency.

There are three respects in which the basic tenets of Dependency and Development, as it was originally formulated, continue to resonate. First, because institutions are the product of history, and specifically of a particular balance of power that congeals at a specific conjuncture, we always have to be attentive to the fact that institutions - domestic as well as global — almost always play a role in reproducing inequality. Thus even if the playing field of the global economy and its variegated governance institutions cannot be reduced to the deterministic formulations of orthodox dependency theory, the playing field nonetheless remains highly skewed, favoring some nations and some interests at the expense of others. Indeed, some commentators have argued that the "development space" is in fact contracting for those who have yet to escape the periphery (Wade 2003; Chang 2002).

Second, even as Cardoso and Faletto were attentive to history and its dead weight, they were always acutely sensitive to the indeterminacies of politics. Indeed, as one re-reads Dependency and Development what is striking is less the structural part of the analysis than the extraordinary range and complexity of the political situations they analyze in Latin America. Their Marxist heritage owes less to the Marx of Das Kapital than to the Marx of The Eighteenth Brumaire. ${ }^{2}$ This point bears emphasis because it stands as an important counterpoint to contemporary versions of structuralism, which are no less deterministic, though certainly more a-social than the Marx of Kapital. These have taken the guise of various rational-choice path dependent arguments, ranging from the initial conditions for establishing property rights (Acemoglu, Johnson, and Robinson 2001) to geography (Krugman 1991; see also Wibbels, this issue). For Cardoso and Faletto, political and social agency matters; history sets conditions, not outcomes. With a note of caution to academics, they emphatically underscored this point in the closing paragraph of Dependency and Development:

The course of history depends largely on the daring of those who propose to act in terms of historically viable goals. We do not try to place theoretical limits on the probable course of future events. These will depend, not on academic predictions, but on collective action guided by political wills that make work what is structurally barely possible (176).

The third point follows directly. Dependency and Development made no apologies for being self-consciously political and critical. As a body of theory, dependency was after all a critique, emanating directly from the Global South, of

\footnotetext{
${ }^{2}$ In Kapital, Marx emphasized the systemic logic of capitalism and presented a deterministic view of history. In The Eighteenth Brumaire he famously identified many classes locked in complex struggles and alliances as the driver of history.
} 
dominant theories of development, and specifically modernization theory. The critical voice of Dependency and Development remains as refreshing today as it was then for two essential reasons. First, as Albert Hirschman (1971) once famously noted, social science inquiry should not limit itself to explaining probabilities, but also aim to uncover possibilities ("what is structurally barely possible" in Cardoso and Feletto's words). And second, we need to be reminded, as Amartya Sen (1999) has done so powerfully, that development is neither growth nor "good governance" but rather what we collectively define it to be, and that such a process can be secured only through continuous and democratic public discussion. ${ }^{3}$

If there is a great deal of continuity between the mode of analysis advanced by Cardoso and Faletto four decades ago and the analytic and methodological discussion in contemporary macro-social science, the same cannot be said about the substantive diagnoses made of the chances of development under conditions of inequality among nations nearly two generations ago and those that seem reasonable today. The constellations of power across nations have changed, and they may be again at a point of transformation today. The same goes for the configuration of dominant and critical ideologies related to these changed and changing realities.

On the one hand, as useful as the core-periphery distinction may have been 40 years ago, the rise of the Asian Tigers and the rapid emergence of China, India, and Brazil have produced a much more complex and multi-layered geo-economic global system. Moreover, this new configuration is neither the product of some global logic of technological convergence ("the earth is flat") nor the transformative forces of the market, but rather the outcome of multiple, specific, and historically determined pathways. Thus even as Brazil, Russia, India, and China are now fashionably lumped into an acronym (BRIC), the nature of their insertion into the global economy (crudely, but illustratively: soy beans, oil, software, and toys) and the social and political conditions under which their economies (though certainly not all of their people) have been catapulted out of the periphery, are marked by far more variation than was the case of the original industrializers. Significantly, if the "origins of capitalism" gave birth to the social sciences and fueled a long, rich, and contentious debate, coming to terms with the new global political economy remains a profound and difficult challenge for the social sciences of today.

On the other hand, just as the transformations of the past four decades have laid to rest high modernist visions of planned development (Scott 1998), more nuanced understandings of the role the state and institutions in general, and the current crisis of the global financial system in particular, have exposed triumphalist notions of self-propelling and self-regulating markets as simplistic ideologies. Doing justice to the legacy of Dependency and Development in these times of defanged ideologies and new uncertainties calls for careful comparative assessments that can help

\footnotetext{
${ }^{3}$ It is especially interesting to note that while democracy hardly seemed a realistic possibility in the Latin America of 1967, it did figure prominently in Cardoso and Faletto's normative perspective. In the closing paragraph of the post-scriptum, written in the late 1970s, they argued that the "battle" was one that pitted "technocratic elitism [against] a vision of the formative process of a mass industrial society which can offer what is popular as specifically national and which succeeds in transforming the demand for a more developed economy and for a democratic society into a state that expresses the vitality of the truly popular forces ..." (Cardoso and Faletto 1979, 216).
} 
identify the specific configurations of institutions, actors, and interests shaping the pathways of global integration.

\section{The Political Economy of Globalization: A Critical, Macroscopic, and Possibilistic Approach}

The articles that comprise this special issue share three key features that, together, define a distinctive approach to political economy. They adopt a critical normative posture, are macroscopic in focus, and self-consciously aim to combine human agency and socioeconomic structure in explaining the contrasting developmental fortunes of countries.

The articles can be considered critical in several key respects. At the most general level, they are attuned to the possibility of asymmetric power relationships across countries, which was at the heart of the notion of dependence, as contrasted with the alternative notion that construes these relations as interdependence. They are also keenly aware that governance institutions, including the state and representative democracy, are circumscribed by relations of power. Likewise, many of the pieces share a concern with detecting emancipatory and transformative strategies that can enhance the possibilities for achieving social justice; that is, they embrace a "possibilistic approach," to use Hirschman's (1971) formulation. Finally, several of the essays take an explicit normative and prescriptive position. Fernando Henrique Cardoso unabashedly argues that what he calls "globalized social democracy," which combines openness to international markets, robust social policies that promote social justice, and a democratically accountable state, is the preferred strategy of development for contemporary Latin American countries. This lays the ground for a lively exchange concerning the feasibility and desirability of globalized social democracy. Peter Evans argues that Cardoso has, essentially, misspecified the constraints facing countries in the Global South, underestimating the barriers to achieving globalized social democracy posed by international economic institutions that tilt the playing field decidedly in favor of counties in the North. According to Evans, a good dose of vigorous "global agency" is thus required from actors in the South to change these institutions before anything resembling globalized social democracy can be achieved. Still, Evans concludes on a strongly hopeful note, drawing lessons from illustrative cases where states in the Global South exercised "global agency" in ways that made remarkable progress toward leveling the international playing field. Gerardo Munck shifts the focus to the consequences of globalized social democracy, raising questions about the desirability of this approach. By comparing globalized social democracy to the alternative, "antiglobalization" strategy, exemplified by Venezuela, Munck argues that there are important trade-offs between democracy and development. Although the globalized social democracy cases (Brazil, Chile) perform better in terms of democracy, they do not perform as well in terms of poverty reduction and the mitigation of inequality. Munck thus concludes: "None of the paths followed by Latin American countries can be held to be preferable across the board."

The contributions share a second key feature: they adopt a macroscopic focus. That is, to use Tilly's (1989) evocative formulation, they focus on "big structures, 
large processes, and huge comparisons." None of the essays offers in-depth case studies of particular countries, sectors, policy episodes, or actors. Rather, they range across multiple countries, though still well within the boundaries of a small or medium-N sample, which ensures that the authors have a good familiarity with the countries they discuss, treating them as cases, not data points. This sets these papers off from large-N, quantitative cross-national research. Moreover, half the contributions are explicitly cross-regional in scope, as Atul Kohli draws comparisons across Asia and Latin America, László Bruzst and Béla Greskovits across Eastern Europe and Latin America, and Jonathan Conning and James Robinson across Africa, Asia, and Latin America. Even the pieces which do not make cross-regional comparisons are macroscopic, focusing on broad processes of development and democratization across multiple countries. Indeed, in his commentary on the six articles, Erik Wibbels pointedly criticizes the macroscopic focus of these works, calling instead for a shift in focus to "micro-foundations." Wibbels argues that "a microfoundational approach to dependency would work toward identifying the key actors-MNC managers, international financiers, politicians, labor market participants, etc.- their preferences, and the constraints under which they operate such that dependency results." Wibbels' call for stronger microfoundations poses a challenge for future research: devising frameworks that successfully integrate macroscopic and microscopic perspectives.

A final distinctive feature of the essays, which stems in part from their critical focus on uncovering possibilities for politically progressive and socially just transformation, concerns their explicit effort to integrate human agency and structural constraints to assess what developmental alternatives are historically viable for different countries. All the authors thus face a common analytical challenge: how to determine the space for agency within the contemporary global political economy. This, in turn, requires a set of tools and methods for mapping the range of feasible developmental options and specifying with precision what is structurally possible. The authors tackle this challenge in different ways, devising distinct strategies for combining agency and structure. These strategies are defined by three key elements: the use of comparison, historical analysis, and multilevel frameworks that link variables at the domestic and global levels. ${ }^{4}$

The systematic use of cross-national comparisons provides one fruitful way to map the range of feasible developmental options. For example, Cardoso uses cross-country comparisons to assess the causal effects of a structural variable hypothesized to have a major impact on developmental fortunes, namely, the level of economic diversification. Drawing on his book with Faletto (Cardoso and Faletto 1979), Cardoso argues that the level of economic diversification is largely a function of how countries were historically incorporated into the global market: "enclave" economies had less diversified economic profiles than countries where production was "nationallycontrolled." At first glance, the distinction between enclave and nationally-controlled economies seems to explain much of the variance in economic performance across Latin America. Yet Cardoso's comparative framework shows that economic structure is not destiny. Despite its enclave past, Chile has performed remarkably well in the

\footnotetext{
${ }^{4}$ For a discussion of the "agent-structure problem" with special reference to regime change, see Mahoney and Snyder (1999).
} 
contemporary era. By contrast, Argentina has performed poorly despite its more diversified economy. To explain overachieving Chile and underachieving Argentina, Cardoso shifts the focus to political variables, especially the quality of state institutions and political leadership. Cardoso's comparative analysis highlights that, within limits, economic diversification can be constructed or, alternatively, destroyed. ${ }^{5}$

Historical analysis is another important technique for assessing what developmental options are structurally possible. The challenge of integrating agency and structure through historical analysis can involve microscopic process tracing to see how discrete choices and chains of events open and close options, to determine the "choice set" actors face in specific episodes and junctures, or to identify "paths not taken." Because of their macroscopic focus, the contributors to this special issue use historical analysis not to zoom in on specific episodes and choice points, but to assess broad cross-national and cross-regional patterns and sequences of transformation. Kohli's contribution offers a good example of this way of using historical analysis. According to Kohli, to understand the options contemporary countries face for "coping" with globalization, one must explore historical processes of state formation and determine whether or not there was a sharp break with the global economy that created national autonomy and state capacity. In Asia, Kohli argues, a rupture with colonialism after World War II provided an opportunity to alter external relations and build more autonomous nationalist states. In Latin America, by contrast, there was no such rupture, and consequently "Latin American countries either remained or became more and more a part of the US's 'informal empire." Asian countries thus enjoy far more leeway than their Latin American counterparts in defining strategies of development. Hence, Kohli concludes, the nationalist states of Asia cope with globalization from a position of strength, whereas the Latin American countries cope with it on "bended knees."

Conning and Robinson's piece provides another example of how historical analysis can be used to map the constraints on the range of feasible developmental options. By using quantitative historical data on export commodities in former European colonies, Conning and Robinson carry out a statistical test of the "enclave thesis" advanced in Dependency and Development, that is, countries with enclave economies perform worse. They find little evidence that whether or not a country was an enclave affects its long-run growth. Conning and Robinson's study thus shows how historical analysis can be used to probe systematically how binding a hypothesized structural determinant actually is. Their analysis suggests that past enclave status does not, in fact, limit a country's developmental fortunes. ${ }^{6}$

A final way the contributors try to assess the space for agency in the global economy involves devising multilevel analytic frameworks. These frameworks aim to situate agents, who are usually not discrete individuals but collective actors, like classes,

\footnotetext{
${ }^{5}$ Cardoso's study raises an interesting set of counterfactual propositions: if the quality of political institutions and leadership in contemporary Chile had been lower, then its recent developmental performance might have been far weaker. Likewise, if the quality of political institutions and leadership had been stronger in Argentina, its performance might have been closer to that of Brazil and Chile, which Cardoso considers successful cases of development.

${ }^{6}$ This is an important claim, because whether or not a country was an enclave is a key variable in Dependency and Development. In his response on this issue, Cardoso states that whether capital and investment are foreign or domestic, not ownership per se, is the key determinant of developmental fortunes. There is clearly much fodder here for an interesting debate on the long-run determinants of development.
} 
movements, and organizations, in the face of constraints at the domestic and international levels. Instead of limiting the focus to a specific aspect of the international or domestic context, the goal is to build a multivariate bridge for causal analysis that connects global economic forces, international institutions, domestic political institutions, especially state capacity, societal forces, and political actors. The challenge is to combine these different kinds of variables into a unified explanation that shows how agents maneuver within, and potentially transform, the structural constraints and possibilities they face. Cardoso's "New Paths" provides a good example of this kind of multilevel analysis. He argues that a country's mode of historical insertion into the global market determines its degree of economic diversification, and this, in turn, conditions a country's prospects for development. Still, these external and internal structural factors alone do not determine how a country will perform. Domestic state and political institutions, as well as the quality of domestic political leadership, also have an important, even decisive, impact. Hence, Cardoso's analysis spans the global economy, domestic economic and state institutions, societal forces, and the style and choices of specific political actors, providing a dynamic explanation for contrasting paths of development across countries. Likewise, Bruzst and Greskovits adopt a multilevel approach in their cross-regional comparative analysis of capitalist diversity in Eastern Europe and Latin America. To understand the contrasting developmental fortunes of countries in the "semi-core," "semi-periphery," and "periphery," they argue it is necessary to bridge the international and domestic levels by considering four key variables: mode of international integration, profiles of global economic insertion, domestic state capacity, and social integration.

With regard to combining agency and structure in the study of development, the contributors focus less attention on domestic social movements and political leaders. Still, there is no necessary barrier to incorporating these kinds of actors and a more explicit focus on leadership into the study of development and globalization. Indeed, expanding the focus to include these other agents could be an important step toward integrating the macro- and micro-foundations of development. A similar point can be made about "cultural structures," which do not figure prominently in the contributions here, although Cardoso raises the cultural dimension in his discussion of the problems of democracy in Latin America, noting the "missing soul" of democracy as a potential hindrance to development.

To conclude, the contributions underscore that critical, macroscopic, and possibilistic political economy offers an exciting and fruitful way to understand the problems and challenges of development in our globalized world.

\section{References}

Acemoglu D, Johnson S, Robinson JA. The colonial origins of comparative development: an empirical investigation. Am Econ Rev. 2001;91:1231-94.

Bardhan P. The political economy of development in India. Oxford: Oxford University Press; 1983.

Brenner R. Agrarian class structure and economic development in pre-industrial Europe. In: Aston TH, Philipin CHE, editors. The brenner debate. Cambridge: Cambridge University Press; 1985.

Cardoso FH, Faletto E. Dependency and development in Latin America. Berkeley: University of California Press; 1979.

Chang Ha-Joon. Kicking away the ladder. Northampton: Elgar; 2002. 
Chibber V. Locked in place: state-building and late industrialization in India. Princeton: Princeton University Press; 2003.

Collier RB, Collier D. Shaping the political arena: critical junctures, the labor movement, and regime dynamics in Latin America. Princeton: Princeton University Press; 1991.

Evans P. Dependent development: the alliance of multinational, state and local capital in Brazil. Princeton: Princeton University Press; 1979.

Evans PB. Embedded autonomy: states and industrial transformation. Princeton: Princeton University Press; 1995.

Haggard S, Kaufman RR. Development, democracy, and welfare states: Latin America, East Asia, and Eastern Europe. Princeton: Princeton University Press; 2008.

Heller P. The labor of development: workers and the transformation of capitalism in Kerala, India. Ithaca: Cornell University Press; 1999.

Hirschman A. A bias for hope. New Haven: Yale University Press; 1971.

Huber E, Stephens JD. Development and crisis of the welfare state: parties and policies in global markets. Chicago: University of Chicago Press; 2001.

Krugman P. Geography and trade. Cambridge: MIT; 1991.

Luebbert GM. Liberalism, fascism, or social democracy: social classes and the political origins of regimes in interwar Europe. New York: Oxford University Press; 1991.

Mahoney J, Snyder R. Rethinking agency and structure in the study of regime change. Stud Comp Int Dev. 1999;34:3-32.

Rueschemeyer D. Toward a new comprehensive social science. In: Hedström P, Wittrock B, editors. Frontiers of sociology. Leiden and Boston: Brill; 2009.

Rueschemeyer D, Huber E, Stephens JD. Capitalist development and democracy. Chicago: University of Chicago Press; 1992.

Sandbrook R, Edelman M, Heller P, Teichman J. Social democracy in the global periphery: origins, challenges, prospects. Cambridge: Cambridge University Press; 2007.

Scott JC. Seeing like a state: how certain schemes to improve the human condition have failed. New Haven: Yale University Press; 1998.

Sen A. Development as freedom. New York: Oxford University Press; 1999.

Snyder R. Politics after neoliberalism: reregulation in Mexico. New York: Cambridge University Press; 2001.

Tilly C. Big structures, large processes, and huge comparisons. New York: Sage; 1989.

Wade R. What strategies are viable for developing countries today? The World Trade Organization and the shrinking of the 'development space'. Rev Int Polit Econ. 2003;10(4):621-44.

Patrick Heller is Associate Professor of Sociology at Brown University. He is the author of The Labor of Development (Cornell University Press 1999) and a co-author of Social Democracy in the Global Periphery (Cambridge University Press 2007). His current research examines the relationship between development, democracy and civil society through a comparative analysis of India, Brazil and South Africa.

Dietrich Rueschemeyer is professor emeritus of sociology at Brown University and an adjunct research professor at Brown's Watson Institute for International Studies. He is the author of Power and the Division of Labor and of Usable Theory: Analytic Tools for Social and Political Research and the coeditor of Bringing the State Back In, among many other books.

Richard Snyder is Professor of Political Science at Brown University. He is the author of Politics after Neoliberalism: Reregulation in Mexico (Cambridge University Press 2001); Passion, Craft, and Method in Comparative Politics (with Gerardo L. Munck, Johns Hopkins University Press 2007); and numerous articles on comparative politics and the political economy of development, especially in Latin America. 